University of South Carolina

Scholar Commons

$1-1994$

Differences in Teaching between Six Primary and Five Intermediate Teachers in One School

Irma J. Van Scoy

University of South Carolina - Columbia, ivanscoy@mailbox.sc.edu

Follow this and additional works at: https://scholarcommons.sc.edu/edcs_facpub

Part of the Education Commons

Publication Info

Published in Elementary School Journal, Volume 94, Issue 3, 1994, pages 347-356.

http://www.journals.uchicago.edu/loi/esj/

(c) 1994 by the University of Chicago

This Article is brought to you by the Instruction and Teacher Education, Department of at Scholar Commons. It has been accepted for inclusion in Faculty Publications by an authorized administrator of Scholar Commons. For more information, please contact digres@mailbox.sc.edu. 


\section{Differences in}

Teaching between Six

Primary and Five

Intermediate Teachers

in One School

\author{
Irma J. Van Scoy \\ University of South Carolina
}

The Elementary School Journal

Volume 94, Number 3

(C) 1994 by The University of Chicago. All rights reserved. 0013-5984/94/9403-0005\$01.00

\begin{abstract}
This study examined differences between primary and intermediate teachers concerning teacher behaviors, teacher communications, grouping, control, and materials. 6 primary classrooms (grades 1 and 2) and 5 intermediate classrooms (grades 4 and 5) were each observed for 4 45-minute periods. In addition, observers, teachers, and 5 students from each classroom responded to 2 vignettes depicting classroom situations and 1 vignette asking respondents to describe a lesson on nutrition. Responses were coded for teacher behaviors, goals, and instructional methods. Analyses of observational data showed that in comparison with teachers in intermediate grades, primary teachers used significantly more sanctions, procedural communications, and total teacher communications. Primary teachers also used a greater proportion of small-group instruction and manipulative materials than did intermediate teachers. Analysis of subjects' responses to vignettes clarified these findings and added further detail.
\end{abstract}

Teachers in both the primary grades (kindergarten through third) and intermediate grades (fourth through sixth) must manage their classrooms and teach students who have a variety of ability levels, personality characteristics, and learning styles. Theories of child development, however, describe important differences between children of primary-grade age (approximately 5-8) and intermediate-grade age (approximately 911) (Damon, 1977; Frostig, 1976; Havighurst, 1972; Piaget, 1973). If students in the primary and intermediate grades differ significantly in cognitive stages, social and emotional needs, perceptual skills, and physical development, and if teaching matches the developmental levels of students, then teaching in the primary grades 
should be quite different from teaching in the intermediate grades.

According to Eccles, Midgeley, and Adler (1984, pp. 297-298), "Most of us would agree that there are systematic changes in the nature of the classroom environment as students proceed through the grades.... However, few studies have attempted to catalogue systematically the nature of these changes." An important question in elementary education is whether differences in teaching between the primary and intermediate grades warrant attention in making decisions in such realms as teacher preparation programs, teacher certification, and day-to-day school operations. Although many teachers, administrators, and other educators might readily address these issues based on their own experiences and beliefs, this study attempts to clarify similarities and differences in teaching between the two levels by analyzing and integrating observational and interview data that were specifically collected to be used in making such comparisons.

\section{Background}

Havighurst (1972) described primary-age children as dependent on adults, with a strong need for adult approval and support. In contrast, he noted that intermediate-age children have much more independence and a diminished need for adult approval and support. Consistent with Havighurst's work, Damon (1977) described children ages 5-7 as viewing authority figures as omniscient and omnipotent and older children as recognizing that an authority may make mistakes or give unfair commands.

These differences in children's views of and interactions with adults are reflected in research describing elementary teachers, classrooms, and students. Effective secondgrade teacher behaviors include individualized attention and adult approval and support, regardless of content area (Tikunoff, Berliner, \& Rist, 1975). These researchers did not find the same consistency of effective behaviors across disciplines for fifth-grade teachers. These results suggest that such behaviors may be particularly important when teaching younger children.

Other researchers have obtained results consistent with younger children's need for more personal and individualized contact with teachers. Brophy and Evertson (1981) found significantly more behavior and nonacademic contacts between teachers and students in the lower grades (second and third) than the higher grades (fourth and fifth) and less whole-class instruction and fewer academic contacts in lower grades. They also found significantly greater use of rewards in the lower grades-a technique noted as "effective with younger adult-criented students" (p. 104).

In Laupa and Turiel's (1986) comparison of first and fifth graders, first graders were more accepting of the legitimacy of adult authority and more likely to choose an adult nonauthority over a peer nonauthority. Blumenfeld, Pintrich, and Hamilton (1987) found that first graders with teachers who were rated high on emphasis of procedures gave more extrinsic reasons for compliance. Fifth graders did not differ based on the teachers' degree of emphasis. This finding indicates that younger students were more strongly influenced by their teachers' behavior. In a study of second, fourth, and sixth grades, Lee (1979) found that students in higher grades expressed a greater desire for more prerogatives in the classroom. This desire was consistent with older students' emerging sense of competence and ability to operate independently.

Piaget (1926, 1947) described egocentricity as an important characteristic of preoperational children (approximately age 2 through 8). Consistent with Piaget's proposal that young children have difficulty understanding another person's point of view, research in classrooms has shown that younger elementary students are less accurate in predicting teachers' expectations (Weinstein \& Marshall, 1984), less accurate in reporting differential treatment from teachers (Marshall \& Weinstein, 1986), and 
less sophisticated in understanding teacher behaviors (Rohrkemper, 1982) than older students. Rohrkemper (1984) found that second- and third-grade students' perceptions of teacher behaviors became more elaborate when teachers used an inductive socialization style. She suggested that "teachers of younger children may want to improve [communication skills] so that students perceive teacher behavior as it was intended" (Rohrkemper, 1982, p. 10). In contrast, fourth- and fifth-grade students' perceptions were not differentiated by teacher's socialization style indicating older students did not require teacher explanations to more accurately perceive teacher behaviors.

The preoperational cognitive level of primary students also indicates that they need many opportunities to manipulate and observe concrete materials such as blocks, cards, games, art materials, and science objects and equipment (Bredekamp, 1987; Kamii \& DeClark, 1985; Kamii \& DeVries, 1978). In addition, younger children's developing perceptual-motor skills (Frostig, 1976) and need for movement and changes in activities (Brophy \& Evertson, 1978) support the need for a variety of materials in the classroom.

In the study reported here, I predicted that, in comparison with intermediate classrooms, primary classrooms would have a greater frequency of overall teacher communications, teacher communications that evaluate students' work or behavior (sanctions), teacher communications focused on nonacademic behavior (procedural communications), and teacher child-centered behaviors such as those that encourage students to try out their ideas or attempt to relate information to the students' perspectives. I also predicted that, in comparison with intermediate teachers, primary teachers would use a greater proportion of individualized and small-group instruction versus large-group and whole-class instruction, teacher-directed work versus independent work, concrete materials versus writ- ten materials, and teacher communications that explain versus nonexplanatory communications. Finally, in comparison with intermediate classrooms, primary classrooms were predicted to have a lesser proportion of teacher communications focused on academic content (handling information) versus all other teacher communications.

\section{Method}

\section{Sample}

The sample for the study consisted of 11 elementary classrooms-three each of grades 1, 2, and 5, and two of grade 4 . These classrooms comprised all of the classrooms at those levels within the same elementary school in a small-city school district in western New York State. Similar classroom arrangements and teaching methods were employed in all classrooms including traditional seating, grouping, and instructional methods and the use of behavior modification techniques. Students came from predominantly white, lower- and middle-income families.

I provided a general summary of the study's procedures at a meeting with the teachers, the principal, and the district superintendent. The summary noted that data on teacher behavior and classroom activities were being collected and that hypotheses and results of the study would be provided after data collection was complete. On my request, all teachers agreed to participate in the study. They had from 9 to 31 years experience, and most had taught the same level (primary or intermediate) since they began teaching.

All students in the 11 classrooms received forms requesting parental permission to participate in the interview portion of the study. Six to 12 out of about 24 students from each classroom returned the form granting such permission. Teachers described the number of returned forms as typical of parental responses to similar school requests. From each classroom, five students who had returned forms were selected randomly to participate. The final 
student sample for the interview portion of the study included 55 students from 6 to 11 years of age.

\section{Procedures and Analysis}

Classroom observation. Each classroom was observed for 4 45-minute periods within 1 week for a total of 33 hours of data. The observations in each classroom took place on 4 separate days and occurred at a different time on each day. Since all classroom activities were relevant, including transition times and routines that did not focus on particular subjects, observations were not scheduled on the basis of beginning and ending subject times. Ten of the 11 classrooms were observed twice in the morning and twice in the afternoon. (Due to scheduling problems, one primary classroom was observed three times in the morning and once in the afternoon.) Classrooms focused on particular subjects at about the same time each day so that the rotating schedule of observations ensured that a variety of subjects and transition times were observed at both levels. The amount of time that each subject was observed was not recorded.

The observation instrument was a modified version of the Joyce Observation System (Joyce, 1970). I used the Joyce instrument because of its established validity and relevance to the hypotheses being tested. The Joyce system records teacher communications every 15 seconds under one of four major categories: sanctions, handling information, procedural communications, and maintenance communications. I modified the instrument to focus more precisely on this study by adding a subcategory on "relating to children's perspectives," coding explanatory statements, and recording data on classroom dimensions other than teacher verbal communications.

The final instrument included the following categories and subcategories: sanctions were coded as positive or negative and then categorized according to the type of student behavior being sanctioned, includ- ing searching (e.g., asking questions, hypothesizing); interpersonal (e.g., interacting with others); attainment; following directions; and general. Handling information (i.e., academic content) was subcategorized as asking a student to hypothesize/observe/speculate, asking a lecture question, giving statements/conclusions, or relating information to students' perspectives. Procedural communications were also categorized according to whether or not they related to students' perspectives. Each communication unit under sanctions, handling information, and procedural communications was also coded as explanatory or nonexplanatory. The "maintenance" category recorded the occurrence of nonsubstantive verbalisms (e.g., "Mmmmmm ... ") or communications unrelated to lessons or classroom procedures.

The following classroom dimensions were recorded once every 5 minutes: grouping (individual, small groups, large groups, whole class), control (teacher-directed vs. independent), and materials used (concrete or written).

Two doctoral students in education collected the data. Each observer collected data at least twice in each classroom. Interobserver reliability of $86.4 \%$ between both observers and the primary researcher was established in a classroom prior to collection of data. Reliability was also calculated for 9 of the 44 observations of the study, with at least one of the nine being done daily. The overall percentage of exact agreement was $84.1 \%$.

For the hypotheses dealing with frequencies of teacher communications, frequencies for primary and intermediate teachers in the appropriate categories were compared using $t$ tests. As in other studies comparing proportions of grouping arrangements, materials used, and locus of control (Marshall \& Weinstein, 1986), hypotheses focusing on proportions were compared using Mann-Whitney tests because of unequal variances and nonnormal distributions. 
Responses to vignettes. Teachers and five students from each classroom responded to three vignettes depicting situations involving classroom instruction and behavioral problems. Teachers read the vignettes themselves. Vignettes were rewritten in simpler language and read aloud to students. I asked teachers and students questions concerning the vignettes in live, tape-recorded interviews lasting from 15 to 45 minutes. Interviews took place during 7 consecutive school days. Four of those days coincided with the days on which classroom observations occurred.

Two of the vignettes dealt with behavioral problems and were designed and revised during research by Brophy and Rohrkemper (1981, pp. 298-299). These two vignettes follow.

1. Bill is an extremely active child. He seems to burst with energy, and today he is barely "keeping the lid on." This morning the class is working on their art projects and Bill has been in and out of his seat frequently. Suddenly, Roger lets out a yell and you look up to see that Bill has knocked Roger's sculpture off his desk. Bill says he didn't mean to do it, he was just returning to his seat.

2. Sarah often seems to be off in her own world, but today she is watching you as you lead a discussion. Pleased to see her attentive, you ask her what she thinks. However, you have repeated her name and she looks startled when she realizes you have called on her. Meanwhile, you realize that she has been immersed in daydreams and only appeared to be paying attention.

In response to these vignettes, all subjects were asked what the teacher would say and do if such an incident occurred in their own classrooms, why the teacher would do this, and how the teacher would think of the student depicted. Students were also asked what they and their classmates would do if such an incident occurred in their classroom.
The third vignette stated that the "class is working on the topic of nutrition-'foods that are good for you.'" Subjects were asked to describe how the teacher would present a lesson on this topic. After subjects gave their initial responses, they were asked follow-up questions based on previous research (Morine-Dershimer, 1978-1979). These questions elicited information on seating and arrangement of the physical environment, materials, directions, objectives, teacher consideration of pupil characteristics, and similarities and differences between the lesson described and typical lessons in the class. To help students understand what was being asked, their questions were slightly reworded versions of teacher interview questions.

I coded vignettes 1 and 2 using a modified version of a system that Rohrkemper (1982, 1984) used to categorize responses concerning teachers' behaviors, goals, and views of the children depicted, and students' reactions to the children depicted. I coded vignette 3 using categories derived from the responses of the subjects concerning grouping arrangements, control, types of materials used, teachers' consideration of pupil characteristics, and teachers' goals. Each category within each variable was treated as zero (not used) or one (used) by each subject. The results of this coding were added to form total scores for teachers and students at each level (primary and intermediate) and for each vignette. Raw numbers are presented for teacher and student scores; however, given the larger number and unequal sample sizes of students, their scores are also referred to in percentages as needed to clarify comparisons.

\section{Results}

\section{Observations}

Table 1, which presents the frequencies of teacher communications, shows that the six primary teachers used significantly more sanctions $(p<.10)$, procedural communications $(p<.05)$, and total communications $(p<.01)$ than did the five intermediate 
TABLE 1. Means (M), Standard Deviations (SD), and Probability Data from $t$ Tests of Primary and Intermediate Teachers' Frequencies of Communications

\begin{tabular}{|c|c|c|c|c|c|}
\hline \multirow{3}{*}{$\begin{array}{l}\text { Type of } \\
\text { Communication }\end{array}$} & \multicolumn{4}{|c|}{ Frequency of Use } & \multirow[b]{3}{*}{$t$} \\
\hline & \multicolumn{2}{|c|}{$\begin{array}{l}\text { Primary } \\
\text { Teachers } \\
(N=6)\end{array}$} & \multicolumn{2}{|c|}{$\begin{array}{l}\text { Intermediate } \\
\text { Teachers } \\
(N=5)\end{array}$} & \\
\hline & $M$ & SD & $M$ & $\mathrm{SD}$ & \\
\hline Sanctions & 309.7 & 72.7 & 238.8 & 51.6 & $1.65^{*}$ \\
\hline Procedural & 299.2 & 62.3 & 219.2 & 51.5 & $2.07^{* *}$ \\
\hline Child-centered & 97.1 & 55.1 & 81.6 & 43.8 & .23 \\
\hline Total & 986.5 & 151.9 & 733.6 & 96.4 & $2.91^{* * *}$ \\
\hline
\end{tabular}

teachers. There were no significant differences between primary and intermediate teachers' use of child-centered communications.

Results on proportions of teacher communications and classroom activities are presented in Table 2. Primary teachers used significantly more individual and smallgroup instruction $(p<.01)$ and concrete/ manipulative materials $(p<.05)$ than did intermediate teachers. No other significant differences were found.

Further examination of the data revealed that half the primary classrooms' tallies recorded as independent work were made in conjunction with tallies indicating that teacher-directed small-group work was occurring at the same time. In addition, approximately four-fifths of the $30 \%$ of instruction recorded as individual/small group in the primary grades was smallgroup instruction recorded at times when those classes were scheduled for language arts (including reading). In contrast, approximately three-quarters of the $16 \%$ of instruction recorded as individual/smallgroup in the intermediate grades was individual instruction and occurred during a variety of subjects.

\section{Responses to Vignettes}

Vignettes 1 and 2. Table 3 displays the number of primary and intermediate teachers who gave the most frequently occurring responses at least once to vignettes 1 and 2. Primary teachers' reports of teacher behavior differed from reports by intermediate teachers in that primary teachers' most frequent responses included changing the classroom environment, requesting an apol-

TABLE 2. Mean Proportion Use of Categories in Primary and Intermediate Classrooms

\begin{tabular}{lccc}
\hline & \multicolumn{3}{c}{ Mean Proportion Use } \\
\cline { 2 - 4 } Activity/ & $\begin{array}{c}\text { Primary } \\
(N=6)\end{array}$ & $\begin{array}{c}\text { Intermediate } \\
(N=5)\end{array}$ & $p$ \\
\hline Communication & .30 & .16 & .01 \\
Teacher-directed work & .63 & .74 & N.S. \\
Use of concrete materials & .25 & .10 & .05 \\
Explanatory communications & .05 & .06 & N.S. \\
Communications handling information & .68 & .75 & N.S. \\
\hline
\end{tabular}


TABLE 3. Number of Primary and Intermediate Teachers Giving Selected Responses at Least Once in Vignettes 1 and 2

\begin{tabular}{|c|c|c|}
\hline \multirow[b]{2}{*}{ Response } & \multicolumn{2}{|c|}{ Teachers } \\
\hline & $\begin{array}{l}\text { Primary } \\
(N=6)\end{array}$ & $\begin{array}{l}\text { Intermediate } \\
\quad(N=5)\end{array}$ \\
\hline \multicolumn{3}{|l|}{ Teacher behavior: } \\
\hline Ask for student input & 4 & 5 \\
\hline Modify teacher & & \\
\hline behavior & 5 & 4 \\
\hline $\begin{array}{l}\text { Request restitution/ } \\
\text { apology }\end{array}$ & 5 & 1 \\
\hline Change environment & 4 & 1 \\
\hline Explain rule & 4 & 1 \\
\hline Give direction & 3 & 0 \\
\hline Isolate & 0 & 3 \\
\hline Help "victim" & 1 & 2 \\
\hline \multicolumn{3}{|l|}{ Teacher goal: } \\
\hline Improve behavior & 3 & 2 \\
\hline Keep things calm & 1 & 3 \\
\hline \multicolumn{3}{|l|}{$\begin{array}{l}\text { Teacher view of } \\
\text { student: }\end{array}$} \\
\hline Underlying causes & 5 & 5 \\
\hline Problem $/$ bad & 4 & 0 \\
\hline
\end{tabular}

ogy or restitution, and explaining why behavior was inappropriate. A response unique to intermediate teachers was to isolate students briefly. Frequencies of primary and intermediate students' responses by vignette are presented in Table 4. Primary students' predictions of teacher behaviors and goals were similar for both vignettes and focused on teacher directing, threatening, punishing, and controlling. In contrast, intermediate students differentiated more between the vignettes and mentioned fewer punishing and threatening behaviors and goals in response to vignette 2 than in response to vignette 1 .

Both primary and intermediate students reported negative teacher views of Bill in vignette 1; however, primary students' views were usually phrased simply, such as "She thinks he's mean." Intermediate students' reports were more qualified and elaborate, such as "The teacher thinks he's not mature enough to act like a fifth grader." A total of $37 \%(19 / 52)$ of intermediate students' responses concerning the teachers' views of students were coded as "can't rate" because of their more elaborate and less absolute descriptions, compared to $25 \%$ $(15 / 59)$ for primary students.

There were some slight differences between primary and intermediate students' reactions to the depicted students. Eight primary students $(26 \%)$ expressed sympathy for the depicted students compared to two intermediate students (8\%). Primary students also more frequently said they would tell the teacher (again, eight [26\%] compared to two [8\%] intermediate students). Eight intermediate students $(32 \%)$ reported that their classmates would tease the depicted students, whereas this response was given by only two younger students (6\%).

Vignette 3. Teachers' and students' responses to vignette 3 are summarized in Table 5. Primary teachers' descriptions of nutrition lessons varied from those of intermediate teachers. Primary teachers' responses included more goals and pupil characteristics that would influence planning and a greater variety of classroom arrangements. The greatest differences between primary and intermediate students' responses were that intermediate students frequently described lessons that included independent work and individual activities, whereas primary students rarely described either.

\section{Discussion}

Generalizability of this study is limited by the fact that data were collected in only one elementary school. The population of the school consisted mostly of white, workingand middle-class students. Schools serving different populations or employing alternative teaching methods might yield different results. In addition, data were collected in only four elementary grades, a small number of students returned permission forms, and only three vignettes were used.

\section{Total Teacher Communications}

I found large differences in the number of teacher communications with students between the primary and intermediate grades. Primary teachers made approxi- 
TABLE 4. Number of Students Giving Most Frequently Mentioned Responses for Vignettes 1 and 2, by Level and Vignette (V)

\begin{tabular}{|c|c|c|c|c|}
\hline \multirow[b]{3}{*}{ Response } & \multicolumn{4}{|c|}{ Students } \\
\hline & \multicolumn{2}{|c|}{$\begin{array}{l}\text { Primary } \\
(N=30)\end{array}$} & \multicolumn{2}{|c|}{$\begin{array}{l}\text { Intermediate } \\
\quad(N=25)\end{array}$} \\
\hline & V1 & $\mathrm{V} 2$ & V1 & V2 \\
\hline \multicolumn{5}{|l|}{ Teacher behavior: } \\
\hline Give direction & 13 & 17 & 17 & 15 \\
\hline Threaten/punish & 25 & 21 & 19 & 10 \\
\hline Request restitution/apology & 2 & 1 & 5 & 1 \\
\hline Ask for student input & 2 & 3 & 1 & 3 \\
\hline Modify teacher behavior & 0 & 1 & 0 & 6 \\
\hline \multicolumn{5}{|l|}{ Teacher goal: } \\
\hline Control/punish & 15 & 7 & 13 & 3 \\
\hline Don't know/can't rate & 7 & 8 & 3 & 11 \\
\hline Improve learning & 0 & 5 & 0 & 10 \\
\hline Improve behavior & 2 & 7 & 1 & 0 \\
\hline Protect others & 0 & 0 & 3 & 0 \\
\hline \multicolumn{5}{|l|}{ Teacher view of student: } \\
\hline Problem $/$ bad & 14 & 4 & 12 & 2 \\
\hline Don't know/can't rate & 4 & 11 & 6 & 13 \\
\hline Good and bad & 7 & 5 & 2 & 0 \\
\hline Normal/good & 3 & 8 & 4 & 7 \\
\hline Other & 2 & 1 & 1 & 5 \\
\hline
\end{tabular}

TABLE 5. Number of Primary and Intermediate Teachers and Students Giving Selected Responses to Vignette 3

\begin{tabular}{|c|c|c|c|c|}
\hline \multirow[b]{2}{*}{ Response } & \multicolumn{2}{|c|}{ Teachers } & \multicolumn{2}{|c|}{ Students } \\
\hline & $\begin{array}{l}\text { Primary } \\
(N=6)\end{array}$ & $\begin{array}{l}\text { Intermediate } \\
\quad(N=5)\end{array}$ & $\begin{array}{l}\text { Primary } \\
(N=30)\end{array}$ & $\begin{array}{l}\text { Intermediate } \\
\quad(N=25)\end{array}$ \\
\hline \multicolumn{5}{|l|}{ Teacher goals: } \\
\hline Inform students & 4 & 3 & 24 & 19 \\
\hline Develop awareness & 2 & 0 & 0 & 1 \\
\hline Influence eating behavior & 2 & 2 & 1 & 7 \\
\hline Other & 2 & 1 & 0 & 0 \\
\hline Pupil characteristics influence plan & 5 & 2 & 4 & 5 \\
\hline Concrete materials & 5 & 4 & 22 & 16 \\
\hline Varied classroom arrangement & 5 & 1 & 12 & 7 \\
\hline Independent activities & 3 & 3 & 2 & 17 \\
\hline Teacher-directed activities & 6 & 5 & 14 & 11 \\
\hline Whole-class activities & 5 & 5 & 12 & 10 \\
\hline Small-group/individual activities & 4 & 3 & 4 & 18 \\
\hline
\end{tabular}

mately 500 more communications per day than did intermediate teachers. This finding is logical, given that younger children depend more on adults and need more adult reassurance and support than older children. Younger students are also likely to act in ways that ensure more contact with teachers. For example, in this study, primary students noted eight times that they would "tell the teacher" in response to vignettes 1 or 2 , although the vignettes clearly indicated that the teacher was already aware of the student's behavior.

\section{Child-centered and Explanatory}

Communications

Primary students might be given help in interpreting teacher behaviors through 
teacher explanations or relation of information to students' perspectives. That four of six primary teachers, but only one intermediate teacher, said they would explain a rule in response to hypothetical children's inappropriate behaviors indicates that primary teachers might provide such explanations more than intermediate teachers. This prediction, however, is not supported by the observational data. The low number of explanatory communications recorded overall is consistent with at least one other study (Blumenfeld et al., 1987).

Although observers rarely categorized teacher statements as explanatory or child centered, teachers at both levels frequently described causes that might underlie the behaviors of students in the vignettes (e.g., problems at home or with schoolwork) and indicated they would modify their teaching behaviors based on consideration of student needs and perspectives. In classrooms, such child-centered teaching behaviors and statements may not be perceived as such by observers.

\section{Procedural Communications}

That primary teachers used more procedural communications than intermediate teachers fits the description of primary children as in the process of being socialized to school. Subjects' responses to vignettes were consistent with these observational findings. Primary teachers focused on giving students information about appropriate behavior, including requesting restitution or an apology, explaining a rule, or giving a direction in response to vignettes 1 and 2 . In contrast, intermediate teachers apparently expected students to know how to behave and emphasized helping them accept responsibility for their actions. Students' reactions to the children depicted in the vignettes also indicated that older students expected peers to be knowledgeable about appropriate behaviors. Intermediate students more frequently predicted that classmates would tease a student for inappro- priate behavior and less frequently indicated that peers would be sympathetic.

\section{Concrete/Manipulative Materials}

Although the observational data showed that primary teachers used a significantly greater proportion of concrete/ manipulative materials than did intermediate teachers, the average use of such materials in primary classrooms was still fairly small at $25 \%$. In response to vignette 3 , both teachers and students described the use of concrete/manipulative materials to a greater degree than classroom observations indicated was typical. Teachers at both levels indicated in response to vignette 3 that the use of manipulatives was beneficial to students but were selective about when they would use these materials based on time available, amount of subject matter that needed to be addressed, students' ability levels, and management considerations.

Although teachers' and students' responses did not indicate differences in the use of materials, the variety of seating and classroom arrangements they proposed did differ by level. In response to vignettes 1 and 2, four primary teachers stated that they would change the environment, whereas only one intermediate teacher gave this response. Many more primary teachers and students also described the use of the floor, tables, or rearranged desks when describing their lessons in response to vignette 3 .

\section{Summary and Conclusions}

Teaching in the primary and intermediate grades was quite different in the school studied. In the classrooms investigated, primary teachers interacted approximately one-third more with students than did intermediate teachers. Furthermore, life in primary classrooms was more highly focused on helping students learn appropriate school behaviors than was the case in intermediate classrooms. Finally, primary teachers used certain grouping techniques, materials, seating and classroom arrangements, and means of relating to their stu- 
dents (i.e., sanctions) more often than intermediate teachers.

This study provides evidence of differences between teaching the upper- and lower-elementary grades that warrant both attention and further research. Additional research identifying differences between teaching in the primary and intermediate grades could provide important information to be considered in school administrative decisions (class size, teacher assignment), teacher education programs, and teacher certification requirements.

\section{References}

Blumenfeld, P. C., Pintrich, P. R., \& Hamilton, V. E. (1987). Teacher talk and students' reasoning about morals, conventions, and achievement. Child Development, 38, 13891401.

Bredekamp, S. (Ed.). (1987). Developmentally appropriate practice in early childhood programs serving children from birth through age 8. Washington, DC: National Association for the Education of Young Children.

Brophy, J. E., \& Evertson, C. (1978). Context variables in teaching. Educational Psychologist, 12, 310-316.

Brophy, J. E., \& Evertson, C. (1981). Student characteristics and teaching. New York: Longman.

Brophy, J. E., \& Rohrkemper, M. M. (1981). The influence of problem ownership on teachers' perceptions of and strategies for coping with problem students. Journal of Educational Psychology, 73(3), 295-311.

Damon, W. (1977). The social world of the child. Washington, DC: Jossey-Bass.

Eccles, J., Midgley, C., \& Adler, T. F. (1984). Grade-related changes in the school environment: Effects on achievement motivation. In J. G. Nichols (Ed.), Advances in motivation and achievement: $A$ research annual: Vol. 3. The development of achievement motivation (pp. 283-331). Greenwich, CT: JAI Press.

Frostig, M. (1976). Education for dignity. New York: Grune \& Stratton.

Havighurst, R. J. (1972). Developmental tasks and education. New York: David McKay.
Joyce, B. (1970). The Joyce system. In A. Simon \& E. Boyers (Eds.), Mirrors for behavior II: An anthology of observation instruments: Vol. A (pp. 11/1-11/5). Philadelphia: Classroom Interaction Newsletter.

Kamii, C., \& De Clark, G. (1985). Young children reinvent arithmetic: Implications of Piaget's theory. New York: Teachers College Press.

Kamii, C., \& DeVries, R. (1978). Physical knowledge in preschool education: Implications of $\mathrm{Pi}$ aget's theory. Englewood Cliffs, NJ: PrenticeHall.

$\rightarrow$ Laupa, M., \& Turiel, E. (1986). Children's conceptions of adults and peer authority. Child Development, 57, 405-412.

Lee, P. (1979). A developmental study of children's prerogatives and constraints in several domains of school experience (Report to the National Institute of Education). Washington, DC: NIE.

Marshall, H. H., \& Weinstein, R. S. (1986). Classroom context of student-perceived differential teacher treatment. Journal of Educational Psychology, 78(6), 441-453.

Morine-Dershimer, G. (1978-1979, Winter). Planning in classroom reality, an in-depth look. Educational Research Quarterly, 3(4), 83-99.

Piaget, J. (1926). The language and thought of the child. London: Routledge \& Kegan Paul.

Piaget, J. (1947). The psychology of intelligence. Patterson, NJ: Littlefield, Adams \& Co.

Piaget, J. (1973). The child and reality. New York: Grossman.

Rohrkemper, M. M. (1982, March). Classroom perspectives: A comparison of teachers', students', and observers' perceptions of teacher behavior. Paper presented at the annual meeting of the American Educational Research Association, New York.

Rohrkemper, M. M. (1984). The influence of teacher socialization style on students' social cognition and reported interpersonal classroom behavior. Elementary School Journal, 85, 244-275.

Tikunoff, W. J., Berliner, D. C., \& Rist, R. C. (1975). Special study A: An ethnographic study of the forty classrooms of the beginning teacher evaluation study known sample (BTES Tech. Rep. No. 75-10-5). San Francisco: Far West Laboratory for Educational Research and Development.

Weinstein, R. S., \& Marshall, H. H. (1984). Ecology of students' achievement expectations: Final report. Berkeley: University of California, Department of Psychology. 